\title{
Isolation and diagnosis of Candida albicans from oral cavity of local chicken and detection some of the virulence factors in Mosul city
}

\author{
Sumaya, Y.A. Al-Dabbagh \\ email: sumayaaldabbagh2018@gmail.com
}

ORCID: 0000-0001-9370-0775

\author{
Department of Microbiology, College of Veterinary Medicine, University of Mosul. Mosul, Iraq.
}

\begin{abstract}
This study included a collection of 30 samples from the mouth of local chickens which suspected effect with candidiasis that is received to the veterinary educational hospital, and 30 samples of crops of newly slaughtered chicken were collected from the local markets of Mosul city, in a period between November 2018 to May 2019, for detection of the Candida albicans. The isolated yeast was diagnosed according to morphological, cultural and biochemical characteristics. 18 isolates of Candida albicans were obtained from mouth samples with a percentage [60\%] and 14 isolates from the crops with percentage [46.6\%]. Virulence factors tests were used for Candida albicans isolates, which included protease, phospholipase, esterase and hemolytic activities of all isolates showed different activity for these factors. The importance of Candida albicans on chicken health was discussed.
\end{abstract}

Key word: Candidasis, Candida albicans, chickens, virulence factors.

\section{Introduction}

Thrush [candidiasis] is one of the economic diseases in poultry because it effects on the poultry industry, it is an opportunistic fungal disease caused by a type of yeast that belongs to the genus Candida [1]. Candida albicans belong to a sporogenus yeast and have a polymorphism appearance by forming pseudo hyphae or hyphae and reproducing by chlamedospores and budding [2].

Crop mycosis in chickens is a primary or secondary infection due to Candida albicans, in addition to other species including C. tropicalis, C. galabrata, C. cruzi and C. parapsilosis. There are many sensitive hosts to infection with Candida, including local chickens, geese, pigeons, turkey, and other birds $[3,4]$. Serious out break reported in many types of birds may occur rarely [5]. C. albicans is considered a part of the normal flora of mouth, esophagus and crop which is commensals on the surface of mucocutaneous in digestive system of human and animals [5,6]. C. albicans an opportunistic pathogen it is activated when predispose factors were available, furthermore the crop containing essential nutrient for yeast growth [7]. Many factors which predispose infection with $C$. albicans, including high humidity and contamination of food with feces of chicken, malnutrition, poor hygiene, crowded housing and associated with other condition such as intestinal coccidiosis [5,8]. Prolonged use of antibiotics leads to strengthening infections of $C$. albicans, furthermore, the age of the bird, chicken under 3 weeks, is more susceptible to infection than older ages [9]. Candida albicans cause inflammation in the oral cavity, esophageal, crop and gizzard because it has some of the virulence factors that enable them to invasion the epithelial cell of the host and avoidance of defense mechanisms in the host [10]. 
The virulence factors include the adhesion factor that tends to attract the fibronectin of the surface cells of the host and avoid host defenses [11]. Extracellular hydrolytic enzyme, which includes phospholipase, Aspartyl proteinase which plays a major role in the pathogenicity of the candida, these factors have the ability to degrade the proteins in extracellular matrix and immunoglobulin as well as it inhibits the phagocytosis and induces inflammatory reactions [12]. Extracellular lipolytic enzymes such as esterase and lipase which contribute to the virulence of Candida albicans, through damage to the cell membrane of the host by digestion the lipids, facilitating tissue invasion in addition to nutrient acquisition[13,14]. Hemolysin is an important virulence factor which is degraded the $\mathrm{RBC}$, and released the iron is that is used by the C. albicans [15].

Affected chickens with $C$. albicans appear complete emaciation depression, weakness, diarrhea and dehydration, and all these factors are responsible for mortality in advanced cases [16]. Clinical symptoms appear only in severe cases with the appearance of superficial oral and crop inflammation, rarely cases may become systemic infections such as nervous, intestinal and renal infections [16]. Usually, the lesions are formed in the upper digestive system, after adhesion C. albicans form the pseudo hypha or hyphae and invade the superficial epithelial cells causing hyperplasia and diphtheritic membrane formation, these lesions which appear as cheesy-like material in the crop, and less frequently in the pharynx and esophagus [17].

Due to the economic losses from candidiasis, which represented by low weight and less production, the aim of this study was to identification the $C$. albicans from the oral cavity and crops of chicken and detect some of the virulence factors for it.

\section{Materials and methods}

A total of 30 samples from the oral cavity of local chicken which is received at the veterinary educational hospital from different regions of the city of Mosul, some of which were suffering from oral membranes infection, for the period between November 2018 until May 2019. The samples were taken from the oral cavity by using sterile cotton swabs, placed in sterile transport medium and transferred directly to the microbiology laboratory for the purpose of isolating C. albicans and performing laboratory tests.

A total of 30 crops of newly slaughtered chicken were collected from the markets of Mosul city and transferred under cool condition to the microbiology laboratory quickly, the crops were opened by a sterile scalpel, and taken a smear from the content by sterile cotton swabs and streaked on Sabouraud Dextrose agar [difco] with $40 \mu \mathrm{g} / \mathrm{ml}$ of chloramphenicol, then incubated at $37^{\circ} \mathrm{C}$ for $24-48$ hours.

Microscopic examinations were used to study the shape, arrangement and stain reaction for suspected colonies by using Gram's stain. The examination was performed using a method of $[18,19]$.

\section{Diagnostic examination}

Diagnosis of $C$. albicans depends on a germ tube formation and demonstration of budding yeast cells and psudohyphae formation [20]. A germ tube formation test was used to distinguish C. albicans from others species, by injecting a small colony of suspected isolates in $0.5 \mathrm{ml}$ of human serum and incubating at $37^{\circ} \mathrm{C}$ for 3 hours. The test was performed according to [21,22] method.

3.1 Chlamydospores formation: Corn meal agar used to observe the chlamydospores and pseudohyphae. The examination was performed according to [23] method.

3.2 Biochemical tests: included Urease test Sugars fermentation and Sugars assimilation tests. These tests were performed according to Cruickshank method [18]. 
3.3 Virulence factors tests: used for $C$. albicans isolates included phospholipase, esterase, proteinase. These tests were performed according to $[24,25,26]$. Hemolysin activity used by Sabouraud Dextrose agar plates supplemented with $7 \%$ sheep blood and $3 \%$ glucose, the test was performed according to [27].

\section{Results}

Through a biochemical and diagnostic examination of 30 swabs taken from the oral cavity of live chicken and 30 crops taken from the newly slaughtered chicken in the city of Mosul, 18 isolates of $C$. albicans were obtained, from oral cavity samples with a percentage [60\%] and 14 isolates from the crops with percentage [46.6\%], as shown in the Table [1].

Table 1. Numbers and percentages of Candida albicans isolated from the oral cavity and corps of local chicken

\begin{tabular}{|c|c|c|c|}
\hline Specimen type & No. of specimen & No. of isolates & Percentage \% \\
\hline Oral cavity & 30 & 18 & 60 \\
\hline Crops & 30 & 14 & 46.6 \\
\hline Total & 60 & 32 & 53.3 \\
\hline
\end{tabular}

4.1 Cultural Characteristics: The colonies of $C$. albicans appeared white creamy colors, smooth, and circular colonies on Sabouraud Dextrose agar.

4.2 Microscopical examination: The cells of Candida albicans appeared Gram positive, oval to spherical or oval to elongated form with buds .as shown in Figure [1].

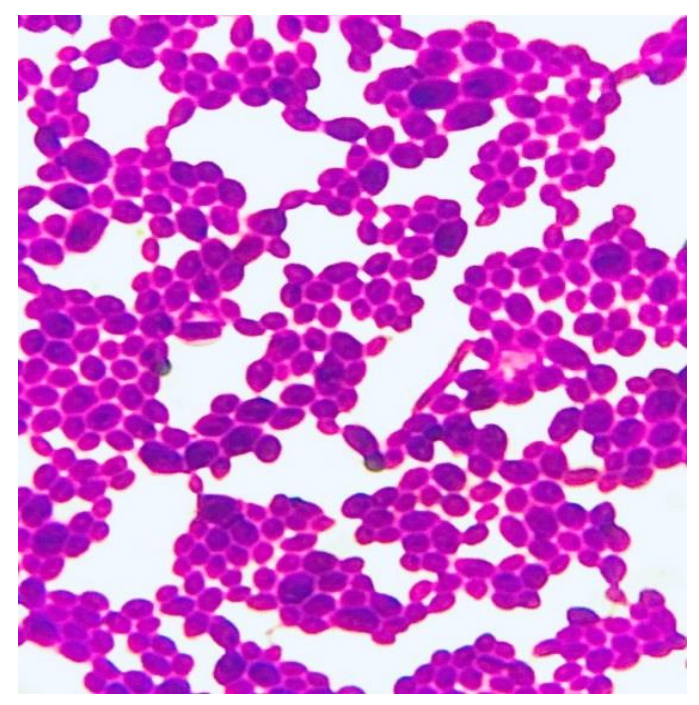

Fig. 1. Candida albicans on Corn meal agar at pm:100 x 
The biochemical tests of Candida albicans isolates showed positive and negative results of these tests as shown in Table 2.

Table 2. Biochemical tests of Candida albicans isolated from the oral cavity and corps of local chicken.

\begin{tabular}{|c|c|}
\hline Test & Result \\
\hline Urease & - \\
\hline Sugar fermenta & \\
\hline Galactose & + \\
\hline Glucose & + \\
\hline Maltose & + \\
\hline Sucrose & - \\
\hline Trehalose & + \\
\hline Sugar assimilat & \\
\hline Glucose & + \\
\hline Maltose & + \\
\hline Sucrose & + \\
\hline Glycerol & + \\
\hline Ribitol & + \\
\hline Lactose & - \\
\hline Arabinose & + \\
\hline
\end{tabular}

4.3 Germ tube formation: The test results showed that all C. albicans isolates formed the germ tube after incubation at $37^{\circ} \mathrm{C}$ for 2-3 hours in $0.5 \mathrm{ml}$ of human blood serum as shown in Figure [2].

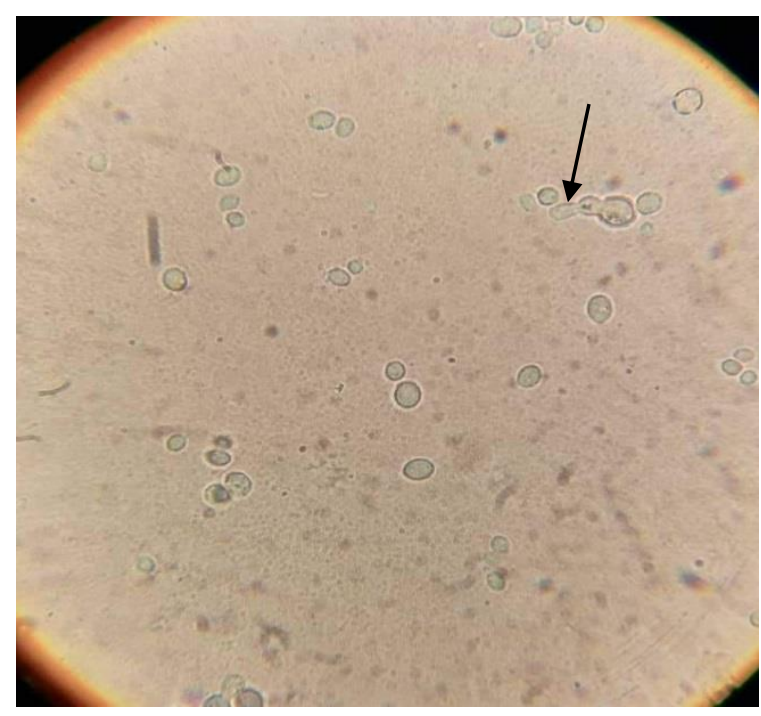


Fig. 2. Germ tube formation by Candida albicans, pm: 100x

4.4 Chlamydospores formation: The results indicated that all C.albicans isolates formed chlamydospores when cultured on Corn meal agar at $30^{\circ} \mathrm{C}$ for $24-48$ hours.

4.5 Virulence factors test: Through avirulence factors examination of $C$. albicans isolates it was found that possess some of the virulence factors as shown in Table 3.

Table 3. Virulence factors of Candida albicans isolated from the oral cavity and crops of local chicken in Mosul city

\begin{tabular}{|c|c|c|c|c|c|c|}
\hline \multirow[t]{2}{*}{ Test } & \multicolumn{3}{|c|}{ Oral cavity } & \multicolumn{3}{|c|}{ Crops } \\
\hline & No. & Positive & $\%$ & No. & Positive & $\%$ \\
\hline Phospholipase activity & 18 & 15 & 83.3 & 14 & 10 & 71.4 \\
\hline Heamolycin & 18 & 14 & 77.7 & 14 & 9 & 64.3 \\
\hline Aspartyl protease activity & 18 & 13 & 72.2 & 14 & 6 & 42.8 \\
\hline Esterase activity & 18 & 9 & 50 & 14 & 5 & 35.7 \\
\hline
\end{tabular}

\section{Discussion}

C. albicans an opportunistic pathogens which colonize the upper gastrointestinal tract in chickens, other birds and human and causes the infection when the predisposing factors for infection were available [28]. Candidiasis is sporadic, but outbreaks occur when proper management protocols are not followed [29].

The present study indicate that all $C$. albicans isolates having a germ tube, which is considered a distinguishtic test for C.albicans from other species. These findings were agreed with other studies [30,31], showed that only $C$. albicans have the ability to form a germ tube in this test which plays an important role in penetration the epithelial layer lining the body and tissues and access to the bloodstream as well as this is believed it is essential for yeast nutrition [32].

Pseudohypha and chlamydospores were seen on Corn meal agar, or as called, cell starvation medium [30]. The result was identical to the result of $[32,29]$ this medium is used for diagnostic this species of Candida [34]. 
Through the microscopical and diagnostical examination of 30 samples for each of the oral cavity and crops of the local chicken, 18 isolates of $C$. albicans were obtained from the oral cavity with a percentage [60\%] and 14 isolates from the crops with a percentage [46.6\%]. The finding contrasted with [34,31] who found [14.3\%,83\%] of C. albicans isolates from domestic chicken and raw chicken meat samples respectively. Other studied indicate that $C$. albicans $36 / 38$ of turkey isolates [27]. Also varied with [35] who found that $32.3 \%$. of candida isolates were C. albicans in crops of broiler chicken, and [86.6\% ] in broiler carcasses [36]. Others publication indicate the incidence of $C$. albicans in broilers crops is lower than the incidence of the pigeons throat [37]. These difference due to the differences in bird species susceptibility to infection with $C$. albicans in addition to environmental conditions represented by the weather, humidity, the seasonal variation and the difference in geographical distribution $[35,38]$ in addition to the crops contain high amount of carbohydrates that is enhancement the growth of C. albicans [29].

C. albicans possesses many virulence factors that enable it to adhere to epithelial cells and invade the host tissue which contributing significantly to the pathogenicity of Candida [3]. The present study results showed that phospholipase the most prominent enzyme activity which formed [83.3\%] of the oral cavity and [71.4\%] of the crops isolates. The result agree closely with [10] who found [78.5\%] of candida isolates having phospholipase activity. And contrast with [27]who found all his isolate [100\%] were positive to phospholipase test. This enzyme plays important role in adherence process to host cells and facilitate their penetration $[10,2,39]$.

Hemolytic activity of isolates under study were observed that $[77.7 \%, 64 . \%]$ for of oral cavity and crops isolates respectively, these results approximately agree with [27] who found that $83 \%$ of candida spp. isolated from turkey having hemolytic activity. Hemolyin, which contribute in C. albicans diseases which facilitates the invasion of host tissues by hypha and spread of infection [40].

The results indicate the proteinase activity of the C. albicans isolates formed $[72.2 \%, 42.8 \%]$ for oral cavity and crops isolates respectively. Whereas [27] showed that [17\%] of turkey isolates having proteinase enzyme. This enzyme facilitates invasion of the host tissue by the damage the host proteins at the site of infection and destroying immunoglobulin, proteinase also inhibits the phagocytosis process and promotes inflammatory reaction [11]. The activity of enzymes for C. albicans isolates is vary depending on the strains and the source of isolates or sit of infection [10,39].

The study showed that $[50 \%, 35.7 \%]$ of $C$. albicans isolates from oral cavity and crops respectively, were positive to esterase activity, this enzyme may participate in the nutrition process of Candida albicans $[13,39,41]$. Through study, we found there is a relationship between the virulence factors levels expressed by a strain and the site of infection of isolated.

\subsection{Conclusion}

The study concludes that Candida albicans is a major causative agent of thrush in local chicken, mouth isolates formed the highest percentage and It was the strongest than crops isolates in terms of virulence factors. Phospholipase and hemolysin were the more powerful virulence factors in the studied isolates. we suggest carrying out Similar studies for other species of Candida in Mosul city.

\section{Acknowledgments}

Thanks and appreciation to the College of Veterinary Medicine, the University of Mosul for their support in the research. 


\section{References}

[1] Bauck, L.: Mycoses. In: Ritchie BW, Harrison GJ, Harrison LR.(eds) Avian medicine: principles and application, $1^{\text {st }}$ ed. Wingers Publishing, Lake Worth, pp. 1005 (1994).

[2] Hirsh, D.C; Maclachlan, N.J. and Walker, R.L.: Veterinary Microbiology $2^{\text {nd }}$ ed. Black well publishing, pp. 153-158 (2004).

[3] Quinn, P.J; Markey, B.K; Carter, M.E; Donnly, W.J; Leonard, F.C. and Maghire,D.: Veterinary Microbiology and Microbial Disease. Blackwell publishing. Company, Iowa. USA. pp. 23-28 (2002).

[4] Moretti, A., Fioretti, D.P., Bonico, L., Pasquali, P., Del Rossi, E.: Isolation of Candida ruogosa from turkeys. J. Vet. Med. B. Infec. Dis. Vet public Health. Vol. 47, pp. 433-439 (2000). https://doi.org/10.1046/j.14390450.2000.00367.x

[5] Songer, J. G. and Post, K.W.: Veterinary Microbiology Bacterial and Fungal Agents of Animal Disease Elsevier sounder. pp. 35-42 (2005).

[6] Chander J.: Textbook of Medical mycology. $2^{\text {nd }}$ ed. New Delhi:Mehta Offest pvt Ltd.Naraina II, pp. 212-231 (2002).

[7] Kono, R., Sakamoto, Y., Hanahachi, A., Kamata, H., Fukuda, Y., Fujiwara, K., Hasegawa, A.: Molecular identification of Candida parapsilosis from crop mucosa in a Cockatiel. J. Vet. Diag. Inves. Vol. 13, pp. 437-439 (2001). /doi/pdf/10.1177/104063870101300515

[8] Kumar, S.K., Kumar, M.R., Mahalakshmi, V., Kavitha, S.: Candidiasis in a Parakeet - an Avenue to Zooanthroponosis. J. of Animal Health and Production. Vol. 5, No. 3, pp. 85-88 (2017). doi.10.17582/journal.jahp/2017/5.3.85.88.

[9] Chute, H.L.: Trush (Mycosis of digestive tract). In: Disease of poultry, Calnek, B.W. , Barnes, H.J., Bread, C.W., Reid, W.M., Yoder, H.W. (eds). $10^{\text {th }}$ ed . IOWA State University press, Ames, La. (2001)

[10] Ells, R., Kilian, W., Hugo, A., Albertyn, J., Kock, J.L.F. and Pohl, C.H.: Virulence of South African Candida albicans strains isolated from different clinical samples. Medical Mycology, Vol. 52, pp. 246-253 (2014). doi: 10.1093/mmy/myt013.

[11] Schaller, M., Borelli, C., Korting, H.C., Hube, B.: Hydrolytic enzymes as a virulence factors of Candida albicans. Mycoses. Vol. 48, pp. 365-377 (2005). https://doi.org/10.1111/j.1439-0507.2005.01165.x

[12] Calderone, R.A., Fonzi, W.A.: Virulence factors of Candida albicans. Trend Microbial. Vol. 9, pp. 327-335 (2001). doi: 10.1016/s0966-842x(01)02094-7

[13] Khalil, I.I., Aldabbagh, S.Y.A., Shareef, A.M.: Isolation, identification and detection of some virulence factors in yeasts from local cheese in Mosul city. Iraqi J. Vet. Science. Vol. 32, No. 1 (2018). http://dx.doi.org/10.33899/ijvs.2018.153802

[14] Sardi, J.C., Scorzoni, L., Bernardi, T., Fusco, A.M., Mendes, G.M.J.: Candida species: Current epidemiology, pathogenicity, biofilm formation, natural antifungal products and new therapeutic options. J. Med. Microbiol. Vol. 62, (Pt 1), pp. 10-24 (2013). doi: 10.1099/jmm.0.045054-0.

[15] Tsang, C.S., Chu, F.C., Leung, W.K., Jin, L.J.: Phopholipase, proteinase and hemolytic activities of Candida albicans isolated from oral cavities of patients with type 2 diabetes mellitus. J. Med. Microbiol. Vol. 56, pp. 1393-1398 (2007). https://doi.org/10.1099/jmm.0.47303-0

[16] Chute, H.L.: Trush [Mycosis of digestive tract). In: Disease of poultry, Calnek, B.W. (ed) $10^{\text {th }}$ ed. Iowa State University, Ames, Iowa. pp. 361-365 (1997).

[17] Velasko, M.C.: Candidiasis and Cryptococcosis in birds. Semin Avian Exotic Pet Med. Vol. 9, pp. 75-79. (2000). https://doi.org/10.1053/AX.2000.4620

[18] Cruickshank, R., Duguid, B.P. Marmion and R.H.A.: Swain. Medical microbiology. 12 ${ }^{\text {th }}$ ed. Vol. 2. Churchill Livingstone, Edinburgh, London and New York (1975). http://www.scirp.org/ ReferenceID=573231 
[19] Morello, J. A., Granato, P.A. and Mizer, H. E.: Laboratory Manual and Workbook in Microbiology Application to Patient Care 7th Edition. The McGraw - Hill Companies, pp. 304 (2003). ISBN-13: 978-0072463545

[20] Kano, R., Sakamoto, Y., Hanahachi, A., Kamata, H., Fukuda, Y., Fujiwara, K., Hasegawa, A.: Molecular identification of Candida parapsilosis from crop mucosa in a cockatiel. J Vet Diagn Invest. Vol. 13, pp. 437-439 (2001). https://doi.org/10.1177/104063870101300515

[21] Koneman, E.W., Allen, S.D., Janda, W.M., Scheckenberger, P.C. and Winn, W.C.: Color atlas and text book of diagnostic microbiology. $4^{\text {th }}$ ed. J.B. Lippincott Company. Philadelphia (1992). http://www.scirp.org/

[22] Forbes, B.E., Sham, D.F. and Wiessfeld, A.S.: Bailey \& Escott's Diagnostic Microbiology. 12 $2^{\text {th }}$ ed. Mosby Elsevier. Taxas, USA. University (2007). http://www.scirp.org?ReferenceID=1418907

[23] Kangogo, M.C., Wanyoike, M.W., Revathi, G. and Bii, C.C.: Phenotypic charectarization of Candida albicans from clinical sources in Nairobi, Kenya. African Journal of Health Sciences. Vol. 19, No. 34, pp. 21-25 (2011).

[24] Price, M.F., Wilkinson, I.D., Gentry, L.O.: Platemethod for detection of phospholipase activity in Candida albicans. Sabouraudia. Vol. 20, No.1, pp. 7-14 (1982). https://doi.org/10.1080/00362178285380031.

[25] Homma, M., Kanbe, T., Chibana, H., Tanaka, K.: Detection of intracellular forms of secreted aspartic proteinase in Candida albicans. J Gen Micro. Vol. 138, pp. 627-633 (1992).

[26] Kouker, G., Jaeger, K.E.: Specific and sensitive plate assay for bacterial lipases. Appl. Envi .Micro. Vol. 53, pp. 211-213 (1987). https://www.ncbi.nlm.nih.gov/pmc/articles/PMC203632/

[27] Sokol, I., Gawel, A., Bobrek, K.: Investigation of the correlation between virulence factors and genotypic profiles of Candida albicans isolated from turkeys. Polish J. Vet. Sci. Vol. 21, No. 1, pp. 29-33 (2018). doi:10.24425/119018

[28] Kunkle, R.A.: Fungal infections. In: Saif, Y.M., Bornes, H.J., Glisson, J.R., Fadly, A.M., McDougald, L.R., Swayne, D.E. (eds). Dis. Poult.11 th ed. IOWA State press, Ames. pp. 901 (2003).

[29] Mugale, M., Bhat, A.A., Gavhane, D.S., Bhat, S.A.: Outbreaks of thrush in pigeons in Punjab State of India. Comp Clin Pathol. (2014). doi:10.1007/s00580-014-1958-y

[30] Habeb, R.A., Ali, H., Hasem, N.A.: Isolation and diagnosis of some Candida spp. yeasts and their sensitivity to some antifungals. Babylon. Uni. J. Pure and Applied Sciences. Vol. 23, No. 3, pp. 955-964 (2015). https://www.iasj.net/iasj?func=fulltext\&aId=107992

[31] Sharma, K.P., Chattopadhyay, U.K., Naskar, K.: Prevalence of Candida albicans in Raw Chicken and Mutton Meat Samples Sold in the Open Markets of Kolkata City of West Bengal. Inter J. of Livestock Res. Vol. 7, No. 5, pp. 5-36 (2017). doi:10.5455/ijlr.20170328034209

[32] Sudbery, P., Gow, N., and Berman, J.: Trend Microbial. Vol. 38, No. 6, pp. 869-881 (2004).

[33] Saroj, G.K., Mallika, R.k., Sugatha, K. and Vivek, H.: Speciation of candida using chromogenic and corn meal agar with determination of fluconazole sensitivity (2013). ISSN 0974-1143

[34] Kemoi, E.K., Okemo, P. and Bii, C.C.: Isolation of Candida species in domestic chicken (gallus gallus) droppings in kabigeriet village, Nakuru country. Kenya. Euro. Sci. J. Vol. 9, No. 36 (2013). ISSN: 1857-7881. ISSN $1857-7431$.

[35] Wyatt, R. D. and Hamilton, P. B.: Candida Species and Crop Mycosis in Broiler Chickens. Poultry Science. Vol. 54, pp.1663-1666 (1975). http://ps.oxfordjournals.org.

[36] El-Diasty, E.M., Ibrahim, M.A. and El Khalafawy, G.K.: Isolation and Molecular characterization of medically important Yeasts isolated from Poultry Slaughter houses and workers. Pakis. J. Zool. Vol. 49, No. 2, pp. 609-614 (2017). doi:http://dx.doi.org/10.17582/journal.pjz.

[37] Kocan, R.M. and Hasenclever, H.F.: Normal yeast flora of the upper digestive tract of some wild Colum birds. J. Wildlife Dis. Vol. 8, pp. 365-368 (1972). 
[38] Talwar, P., Chakrabarti, A. and Chawla, A.: Fungal diarrhea association of different fungi and seasonal variation in their incidence. Mycopathologia. Vol. 1, No. 110, pp.101-105 (1990). https://doi.org/10.1007/BF00446998

[39] Rangel, R.J.T., Pérez, F.E., Lozano, H.V., Quintana, L.A.S., Montoya, A.M., Rodríguez, C.E.L. and González, G.M.: In vitro determination of hydrolytic enzymes and echinocandin susceptibility in mexican clinical isolates of Candida glabrata Sensu Stricto. Jundishapur. J. Microbiol. Vol. 12, No. 6, pp. 85-92 (2019). doi:10.5812/jjm.85092.

[40] Luo, G., Samaranayake, L.P. and Yau, J.Y.: Candida species exhibit differential in vitro hemolytic activities. J Clin Microbiol. Vol. 39, No. 8, pp. 2971-2974 (2001). doi:10.1128/JCM.39.8.2971-2974

[41] Naglik, J.R., Challacombe, S.J. and Hube, B.: Candida albicans secreted aspartyl proteinases in virulence and pathogenesis. Microbiol. Mol. Biol. Rev. Vol. 67, pp. 400-428 (2003) https://doi.org/10.1128/mmbr. 